\title{
SHORT-EARED OWLS NEAR EDMONTON, 1970-1973
}

\author{
by KEN TRANN*
}

The December, 1973, issue of the Blue Jay contained a report entitled "1972 Alberta Raptor Banding Report" in which Chris Rees wrote, that "Two large concentrations of Short-eared Owls could be noted, one north and one south of the city of Edmonton. Several members of the group worked very hard in the area south of the city finding 18 to 20 nests." I was one of the members most active in the area, and I thought a more comprehensive account might be interesting to others.

This report really begins 2 years earlier. In April, 1970, north of Edmonton, near Namao, wherever we drove or walked in an area of approximately 25 sq. mi., an owl of this species could be observed flying over fields or perched on a fence-post. They frequented fields with grass or stubble or grassy edges of dirt fields or grassy ditches. The birds were studied as often as possible during the next month. We plotted territories on maps and watched courtship displays. We were able to locate at least 20 pairs. The fïrst nest was found on May 20, 1970 , in a grassy area bordering a grain field. Between May 20 and June 22 we found 16 nests in this area in all stages of development. For example, on May 26 a nest was found containing 3 eggs and 2 nestlings and on June 22, almost a month later, another nest was found containing 6 eggs.

Many nests were found in stubble but they were usually destroyed by farming operations. On three occasions,

*5823121 Ave.

Edmonton, Alta.

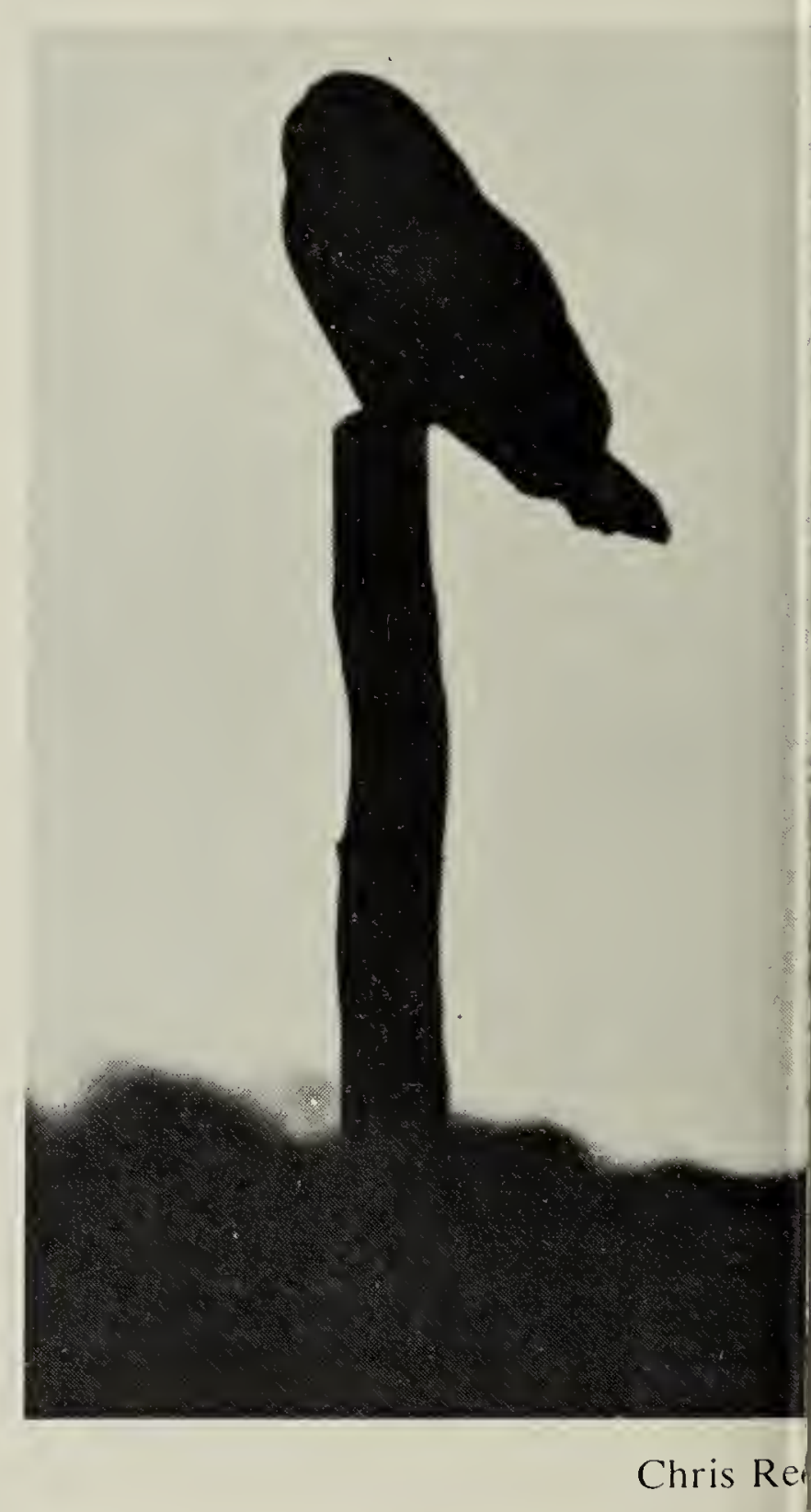

Silhouette of Short-eared Owl on fence-po

to prevent destruction by the plow, w asked the farmer's permission to erer warning poles 10-15 feet on either sid of the nest. When a farmer saw th marker he worked around the nes Co-operation was excellent wheneve we alerted the farmers but we ofte had trouble finding out who owned th land. Consequently, we were too lat to save some nests. Many nests wei destroyed by the plow, some b 
TABLE 1

Individual Short-eared Owl Nest Data

$\begin{array}{ccc}\text { Nest } & 1970 & \\ \text { No. } & \begin{array}{c}\text { Eggs \& } \\ \text { Young }\end{array} & \begin{array}{l}\text { Fledged } \\ \text { Young }\end{array} \\ 1 & 5 & 2 \\ 2 & 9 & 9 \\ 3 & 1 & 1 \\ 4 & 1 & 0 \\ 5 & 7 & 7 \\ 6 & 5 & 0 \\ 7 & 1 & 0 \\ 8 & 7 & 7 \\ 9 & 3 & 0 \\ 10 & 6 & 0 \\ 11 & 5 & 0 \\ 12 & 5 & 0 \\ 13 & 5 & 5 \\ 14 & 3 & 3 \\ 15 & 6 & 6 \\ 16 & 5 & 1 \\ \text { Total } & 74 & 40\end{array}$

$\%$ fledged each year

$54 \%$

1972

$\%$ fledged both years

$\begin{array}{lll}\text { Nest } & \text { Eggs \& } & \text { Fledged } \\ \text { No. } & \text { Young } & \text { Young }\end{array}$

*See text - Redtail Predation.

$\begin{array}{rrr}1 & 8 & 8 \\ 2 & 4 & 4 \\ 3 & 10 & 6 \\ 4 & 4 & 4 \\ 5 & 10 & 8 \\ 6 & 9 & 9 \\ 7 & 5 & 5 \\ 8 & 6 & 6 \\ 9 & 9 & 9 \\ 10 & 5 & 5 \\ 11 & 8 & 8 \\ 12 & 9 & 9 \\ 13 & 4 & 4 \\ 14 & 2 & 1 * \\ 15 & 4 & 4 \\ 16 & 2 & 2 \\ & 99 & 92\end{array}$

$93 \%$

$76 \%$

predators and some were deserted, cause unknown.

Short-eared Owls were noticeably absent in 1971 both in the 1970 and 1972 study areas. The appearance and disappearance of these birds depends entirely on the availability of prey, which is almost exclusively mice. On

one occasion, however, I frightened ar owl away from a freshly killed Savan nah Sparrow, but A. C. Bent lists $75 \%$ of the prey as mice and $25 \%$ as bird and insects. ${ }^{1}$

In 1972 a 25 sq. mi. area was studiec near Beaumont, south of Edmonton Birds were fïst seen (2) in early April

TABLE 2

$\begin{array}{ccccc}\text { Year } & \begin{array}{c}\text { Total } \\ \text { Nests }\end{array} & \text { Complete } & \text { Incomplete* } & \begin{array}{c}\text { Total } \\ \text { Failures }\end{array} \\ 1970 & 16 & 11 & 5-4 \text { failed } & 8 \\ 1972 & 16 & 14 & \begin{array}{c}1 \text { ( } 4 \text { young) } \\ \text { (2 poung }\end{array} & 0\end{array}$

*Nests found with young in advanced stages or nests that were destroyed before completion. 


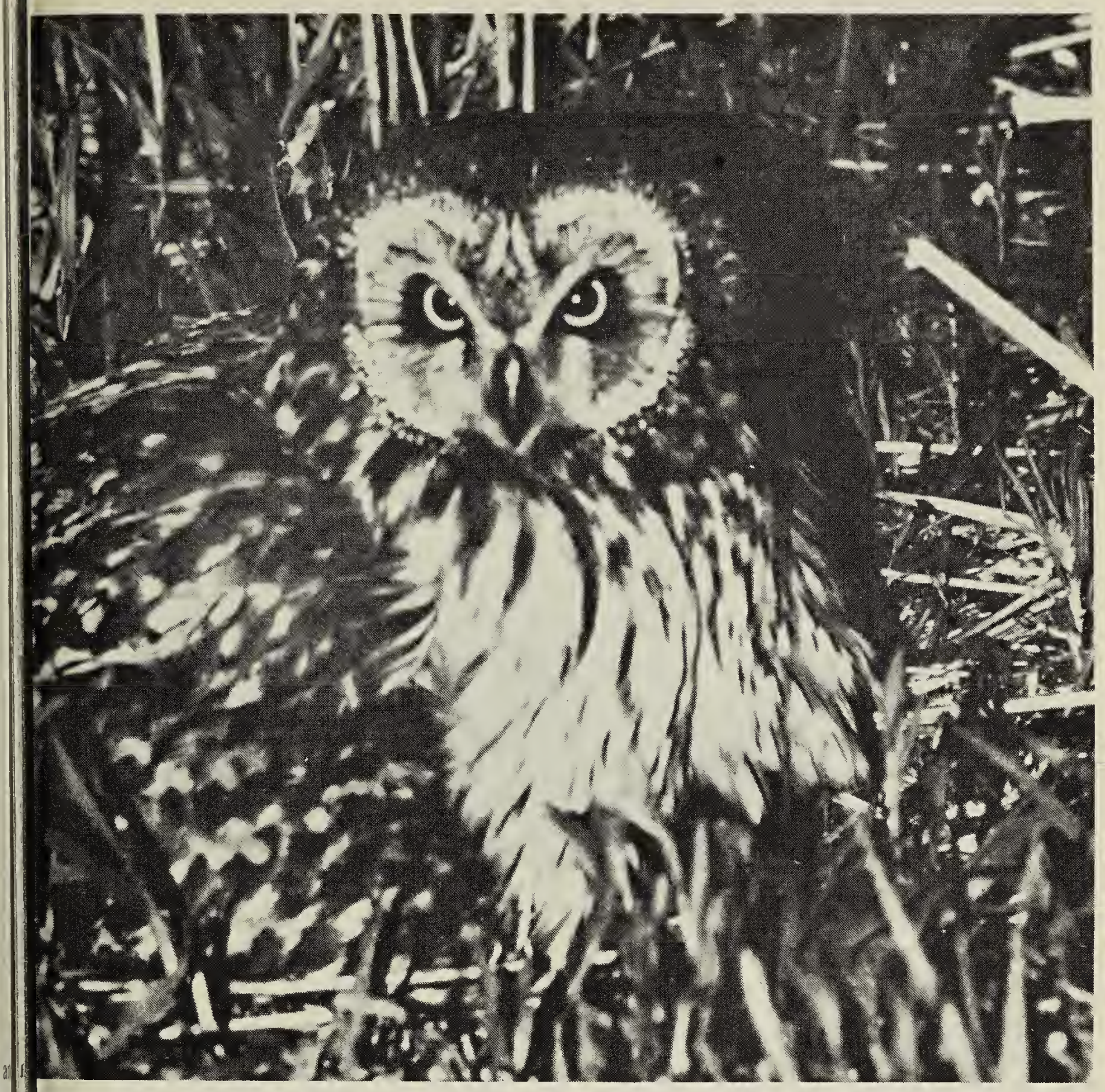

Eemale Short-eared Owl on nest

Chris Rees

By the end of April, birds could be een wherever one travelled within his area. The habitat was similar to he Namao site: open country, grain elds, grassy ditches and mice in abunance. Between May 30 and July 4 we bund 16 nests. Clutch size varied rom 4 to 10 eggs. Some nests were ound in advanced stages of developlent, so the original clutch size is nknown. Because young may leave he nest 2 to 3 weeks after hatching, hen a nest was found containing few irds we called it an incomplete lutch. We searched the immediate
TABLE 3

Clutch Size (complete clutches only)

$\begin{array}{ccc}\text { Clutch } & 1970 & 1972 \\ 4 & 0 & 4 \\ 5 & 6 & 2 \\ 6 & 2 & 1 \\ 7 & 2 & 0 \\ 8 & 0 & 2 \\ 9 & 1 & 3 \\ 10 & 0 & 2\end{array}$

Total

11

14 


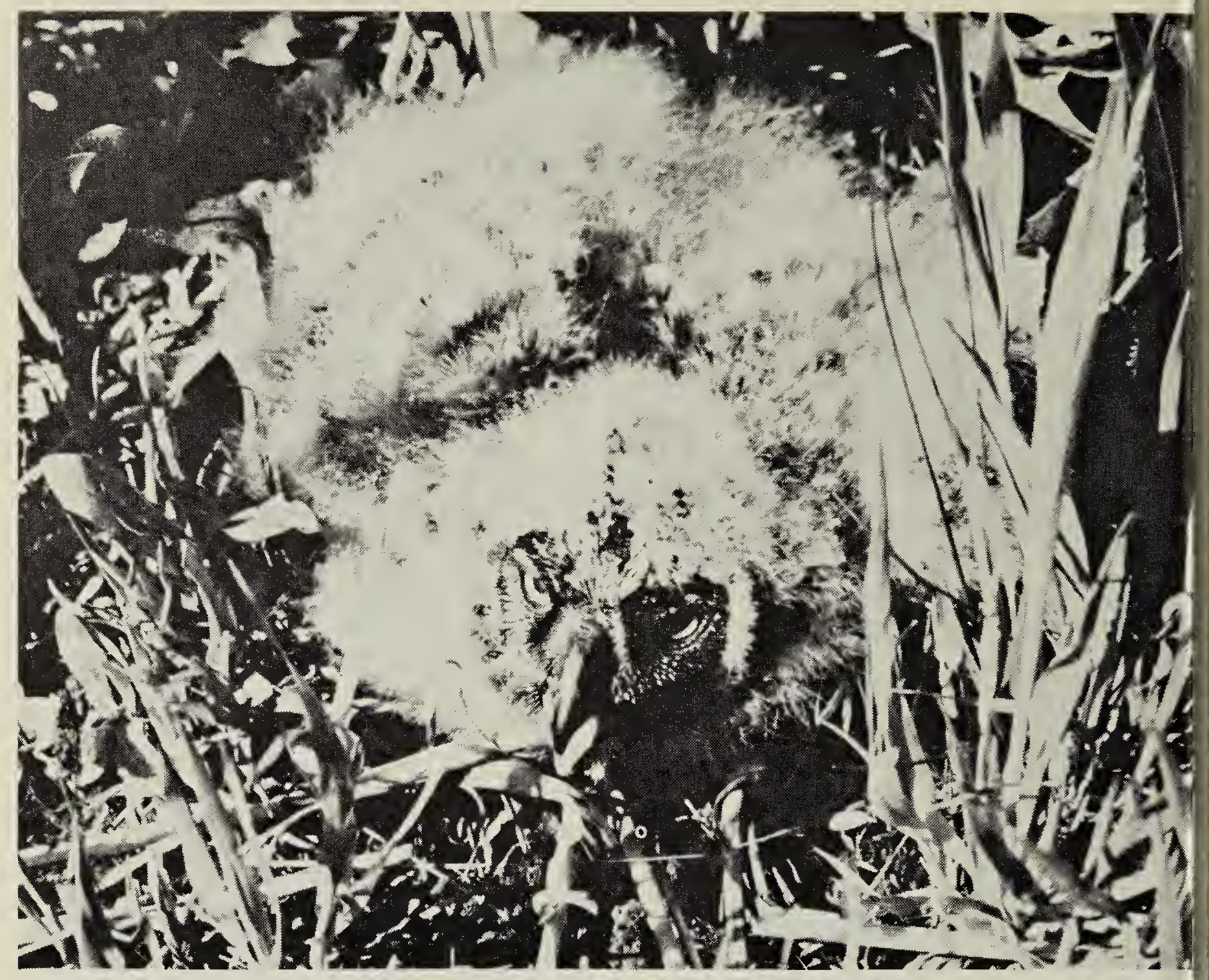

Young Short-eared Owl, 2-3 weeks old

Chris Rec

area but could find nothing. Because they are known to crawl some distance, it is conceivable that these nests contained more young at an earlier date.

Hatching was considerably more successful in 1972. Nests were not hindered by farming operations as was the case near Namao in 1970. On one field trip I observed a Short-eared Owl attacking a Red-tailed Hawk. Through binoculars I saw the hawk drop its cargo. I ran out to the field and found a young Short-eared Owl, slightly ruffled but unharmed! On further investigation, I found the nest with the female and one young, both dead. The carcasses were fresh with no clues as to how they were killed.

Territorial establishment was not observed. A pair could be found nesting in a field with another pai only a short distance away. It was com mon to observe four to six birds hunt ing the same tract of land. Althoug we found 16 nests in 25 sq. mi., othe pairs successfully concealed thei nests. We observed the familiar warn ing signals from disturbed owls bu closer scrutiny of the area revealer nothing. Their behaviour when an ob server approached a nest is wortl mentioning. The male usually ap peared high above when an observe was still $1 / 4$ mile from the nest. As on got closer to the nest and the hidder female, the male dropped lower and lower - circling and "barking". Wher the nest was just a few feet away the male crash dived to the ground - and "crash" is not an exaggeration. Ho would dive towards the ground awa! from the nest, hit with force enough te 
